\title{
A THEORY OF INTERNATIONAL MIGRATION FLOWS: UNITED STATES IMMIGRATION FROM MEXICO
}

\author{
Philip E. Graves and Thomas A. Knapp*
}

\section{Introduction}

Attempts to understand international migration flows have taken several approaches. From a trade theory perspective, international migration is viewed as an equilibrating mechanism: given variations in initial endowments, some combination of trade or factor flows results in factor price equalization (see Mundell, 1957 or Samuelson, 1948, 1953). Economists, demographers and other social scientists have devoted considerable effort to exploring the impacts of migration on the quality of life, either of the migrant or at the origin or destination of his journey.

The economists' traditional approach to migration, especially that occurring within a country, has been to view it as labor's response to income differentials across space. Variation in income tends to correspond to variation in utility or well-being in this view. In such a model, the persistence of spatial wage differentials implies that the area under consideration is in persistent disequilibrium. Yet, within the United States, estimated income coefficients in net migration equations are often insignificant and sometimes of the wrong sign.

To explain some of the anomalies arising from the disequilibrium framework, recent work (see Graves, 1979 or Graves and Linneman, 1979) has taken an equilibrium approach to migration. In this view, full information and mobility lead to compensating differentials in labor markets, hence wage and income variation over space do not correspond to utility variation in light of substantial variation in amenitiesincomes are high in locations which are undesirable and low in areas which are desirable. Hence, in empirical work one must control for amenity variation to arrive at accurate assessments of the impact of income variation on migration. Only after controlling for amenities will income reflect the disequilibrium notion which earlier writers had in mind.

Yet the equilibrium model is more complicated than indicated in the more recent writings cited above. There are "degrees of equilibrium" in the complicated interactions among firms and households-at a point in time income differentials will tend to equate utility across space, but those income differentials will themselves give rise to spatial variation in firm profitability, unless the differentials should by some unlikely coincidence correspond exactly to offsetting spatial variation in other costs of production. Hence firms will move to lower wage areas over time which will tend to eliminate the income differentials but which will tend to create still other differentials, rent differentials. As the desirable locations expand in size, rents will rise (at more accessible locations as stressed by urban economic theory or, more generally, at any locations which are attractive such as along oceans, near shopping or entertainment and the like). It is apparent that the interaction between firms and households in a longer run notion of equilibrium requires consideration of rents: the compensation received in undesirable locations will be some blend of higher wages and lower rents (the blend need not, incidentally, be comprised of shares bounded by zero or one). See Graves (1983) for further detail on these points.

What has the preceding to do with international migration for which the equilibrium view is hardly tenable? The existence of the U.S.-Mexico border clearly interrupts the equilibrating forces regardless

*University of Colorado. An earlier version of this paper was presented at the 2nd Conference on Regional Impacts of U.S.Mexico Economic Relations, May 1983. We wish to acknowledge the helpful comments of program participants. 
of their nature. Yet it will be seen in the following sections that recognition of the existence of equilibrating tendencies, even in the international setting, provides useful insights into the migration phenomenon. Existing and future work will be seen to be far easier to understand and interpret.

Section II lays out in detail a theoretical model of migration as applied to the international setting. Section III presents some limited and tentative empirical observations and suggests the knowledge which might be needed for a more precise understanding of the utility differentials between countries which give rise to migration, legal or illegal. Section IV concludes the paper and indicates the policy relevance of the type of work suggested by the model.

\section{A Theory of International Migration}

For simplicity, we posit a world comprised of only two locations, the United States and Mexico. Results are, however, readily generalizable to the many-country case and recognition will also be given to the fact that these nations are nonuniform in terms of amenities, income, lot size, and leisure. The formal model, apart from variations necessary for application to the international setting, is laid out in detail in Graves and Linneman (1979) and will only be briefly outlined here.

Let potential migrants possess the following utility function to be maximized:

$$
\text { (1) } U=U(A, X, L, S)
$$

In this expression, $\mathrm{A}, \mathrm{X}, \mathrm{L}$, and $\mathrm{S}$ represent, respectively, amenities, ordinary goods, leisure, and lot size. A few general points merit mention at this point: (1) The process is in fact a present value of the multiperiod utility stream obtainable in either Mexico or the U.S. which is to be compared to a corresponding present value of cost of relocating. (2) For international migration there is greater than usual likelihood that the migrant will be unable to obtain his "best" bundle (that associated with the solution to the constrained optimization problem under perfect information and infinite divisibility assumptions) for two reasons. First, imperfect information and mobility suggest that the individual may be away from equilibrium and, second, the types of amenities demanded (perhaps the existence of hispanic neighborhoods) may reduce the feasibility set so that the actual best location within the United States may not correspond to tangency achievable if many destinations were feasible. (3) A final point relates to a problem that is of little consequence in the within-country context but which becomes more important in the international migration setting. The driving influence on migration in the within-country equilibrium model is changing demands for amenities. While the goods, lot size, and leisure desired are endogenous, they will tend to react somewhat passively to migration rather than being an important determinant. To be sure, the choice of location will have a bearing on each of these decisions (e.g., skis versus tennis rackets or less market labor supplied in warm climates relative to cold or smaller lots being selected in desirable locations with high rents). But, within a country there is little in the way of institutional or historical constraints on goods, lot size, or leisure decisions; hence they are likely to be quite similar in various locations. For international migration this is not so-the vector of goods and lot sizes available may differ dramatically across locations, and institutional arrangements as to working hours, conditions, fringes and the like may also vary importantly.

The utility function represented in Equation (1) is to be maximized subject to a Beckerian full-income budget constraint:

$$
\text { (2) } \mathrm{w}^{*}(720) \pm \mathrm{Y}_{0}=\mathrm{I}^{*}=\mathrm{P}_{\mathbf{x}} \mathrm{X}+\mathrm{w} * \mathrm{~L}+\mathrm{P}_{\mathrm{s}} * \mathrm{~S}
$$

In this formulation, the asterisks indicate variables which contain hedonic components. That is, the more desirable locations may be expected (though this need not always be the case) to possess lower wages and higher rents than would be the case for less desirable locations (see Rosen, 1974, for greater detail on the two-stage hedonic procedure for inferring demands in implicit markets). Again, some comments are in order when this constraint is applied to the international migration setting. First, the hedonic compensation structure for a particular skill group within the U.S. may differ quite a bit from that which would emerge were the U.S. comprised of individuals similar in tastes and income to potential Mexican immigrants. Hence, certain locations may be a "bargain" or "overpriced" in terms of wages 
and rents to an immigrant which would not be so characterized by native U.S. citizens. Second, Yo which is the endowment income received which is independent of participation in the labor market, is likely to differ depending on which country is selected-export restrictions on capital and access to unemployment insurance and the like will make Yo differ across countries. Also, unique, or largely so, to the international setting is the fact that the $\mathrm{X}$ and $\mathrm{P}_{\mathrm{x}}$ vectors are likely to be quite different in the destination as opposed to the origin country. Within a country taste similarity and relatively low transportation costs will result in little variation in the goods vector or its price across locations. This is not at all likely for international migration due to both import restrictions which vary among countries and taste for income variation among societies.

Returning to the hedonic compensation structure, two additional points must be raised regarding Equation (2), the budget constraint. The first observation is that the existence of wage compensation for amenities is likely to result in different work/leisure decisions in each location-moreover, the institutional setting in the U.S. and Mexico may impose constraints on working conditions which further complicate the work/leisure decision. Potential migrants who may have only heard of the typical wage differential may be made either better or worse off than they expected $a$ priori.

Finally, and of least familiarity to non-urban economists, is the $\mathrm{P}_{\mathrm{s}} * \mathrm{~S}$ term-the rental price of land will be importantly related to the amenities available at alternative sites (e.g., land is much more expensive in central areas due to access to centrally located employment opportunities or is much more expensive along oceans or near shopping and entertainment). Hence, at more expensive locations land will be economized upon in the production of housing implying greater density at high-priced locations. Depending on preferences and past experience with living at various densities, the hedonic rent structure may have a great impact on the satisfaction a potential migrant will receive. For example, a Mexican worker in Merida may have heard of high wage job opportunities in San Diego but he may not have heard of the high rents also associated with that location. This is particularly true in light of the great variation in rents within a given city and the limited sources of information available to the migrant. Note that the impact of the hedonic rent structure on the migrant's ability to purchase various goods depends on the elasticity of demand for lot size; if this is unity, then (assuming independence between amenity demands and lot size demands) the same amount of income will be spent on land at all land prices. What will differ at various locations is observed living conditions (crowding and the like). Of course, the price elasticity of demand for lot size need not be unity, and the potential migrant may have his desires to consume other goods altered in unexpected ways at his destination.

The first-order conditions for this constrained optimization problem will not be presented here (see Graves and Linneman, 1979, for a full discussion). However, the discussion to this point has pronounced implications for observed migration flows. First, as with all existing discussion of Mexican/U.S. migration, the presence of a border preventing equalization would strongly suggest that utility in the U.S. should be higher than in Mexico for most potential migrants:

\section{(3) Uu.s. $>U_{M}$}

But note that, even in this disequilibrium setting all of the preceding discussion has bearing. The utility gains may be quite different than one would suppose from merely looking at income differentials as is so frequently done. The income differentials could be (but probably are not) almost completely offset by disamenities, higher goods prices, larger land rents or institutionally determined but undesirable working conditions. Since income differentials can either overstate or understate by a large amount the utility gains to be had from migration, we turn now to some tentative empirical insights for the case of Mexican/ U.S. migration flows.

\section{Empirical Observations and Insights Relating to the Model}

Very little in the way of systematic comparisons between the living conditions in Mexico and in the U.S. has been conducted. Much of what follows is, as a consequence, a bit speculative. However, that speculation is guided by the preceding discussion. Since utility will depend on amenities, goods consumption, leisure, and density, the type of information necessary to obtain insights on the real utility gain resulting from movement to the U.S. is knowable. The following information would, at a minimum, be necessary in order to compare utility gains from movement to the U.S. with the status quo: 
*Amenity supplies at various origins and destinations must be known (these would include: climate, culture, educational quality and access, crime, pollution, population size as a proxy for numerous urban variables, access to recreational opportunities such as oceans, rivers, mountains, or lakes, and so on).

*Goods, supplies and prices at various origins and destinations must be known (this will involve consumer surplus calculations for the "all-or-nothing" comparisons which will need to be made for certain goods as well as the more commonly-noted index number problems which must be faced).

*Institutional features affecting the work/leisure decision must be known at the origins and destinations (this would include: working conditions which will be quite different for legal versus illegal immigrants, access to unemployment insurance in each country, traditional differences in hours worked, and so on).

*Density conditions (the inverse of lot size) and the extent to which amenities are capitalized into prices or wages must be known at both origin and destination (this would include an understanding of how preferences being different might lead to a capitalization which is inappropriate to immigrants, leading them to receive less utility than one would otherwise expect; traditional lot size arrangements would need to be looked at in both countries and hedonic analyses would need to be conducted).

The preceding information would enable researchers to assess the utility gains to be had from movement to the U.S. from Mexico. However, full understanding of the migrant flows will require examination of the socio-demographic characteristics of the sending population. The list of variables of this nature is long: age, education, marital status, family size, race, wage level, wealth, health, employment status and changes in all of these variables and others all affect the probability of moving (see Graves and Linneman, 1979, or Linneman and Graves, 1983, for greater detail). The amount of movement actually observed or predicted to occur in the future will depend not only on the utility gain to be had but also on the host of preceding variables which condition the likelihood of acting on the existence of the utility gains.

By way of illustration, Greenwood and Lillydahl, 1982, note that it takes 15 years for a Mexican migrant's income to catch up with U.S. incomes for those of comparable skill-level-this provides an additional explanation for the negative influence of age on migration, strengthening the discounting argument. Schultz, 1975, argues that education enables people to better adapt to disequilibria in the labor market. This is consistent with a study cited in Hansen, 1981, which indicated that young, well educated Mexicans make up a sizeable portion of the Mexican migrant flow in the U.S. The informationprocessing efficiency argument of Schultz may also explain the Hansen finding that the younger, well educated Mexican migrants tend to go to areas other than the heavily Mexican-populated border regions, the latter being also relatively poor.

\section{TABLE 1}

Comparative Climate Amenities: Selected Mexican and U.S. Cities

\begin{tabular}{lcccc}
\hline Mexico: & $\begin{array}{c}\text { Annual Heating } \\
\text { Degree Days }\end{array}$ & $\begin{array}{c}\text { Annual Cooling } \\
\text { Degree Days }\end{array}$ & $\begin{array}{c}\text { Temperature } \\
\text { Variance }{ }^{\circ} \mathrm{F}\end{array}$ & $\begin{array}{c}\text { Ave. July } \\
\text { Rel. Humidity }\end{array}$ \\
City & 4471.9 & 61.1 & 39 & $63 \%$ \\
Guayamas & 259.8 & 1290 & 42 & $73.5 \%$ \\
La Paz & 976.5 & 149.2 & 25 & $76 \%$ \\
Manzanillo & 322.4 & 3986.4 & 25 & $77 \%$ \\
Mazatlan & 0 & 3483.4 & 30 & $72 \%$ \\
Merida & 3.1 & 2060.5 & 32 & $67 \%$ \\
Mexico City & 933.4 & 114.9 & 42 & $62 \%$ \\
Monterrey & 2230.4 & 143.6 & 17 & $70 \%$ \\
Salina Cruz & 315 & 3206.2 & 21 & $81 \%$ \\
Vera Cruz & & & & $\%$ \\
\hline
\end{tabular}


TABLE 1 (continued)

Comparative Climate Amenities: Selected Mexican and U.S. Cities

\begin{tabular}{lcccc}
\hline $\begin{array}{l}\text { United States } \\
\text { SMAS's }\end{array}$ & $\begin{array}{c}\text { Annual Heating } \\
\text { Degree Days }\end{array}$ & $\begin{array}{c}\text { Annual Cooling } \\
\text { Degree Days }\end{array}$ & $\begin{array}{c}\text { Temperature } \\
\text { Variance }\end{array}$ & $\begin{array}{c}\text { Ave. July } \\
\text { Rel. Humidity }\end{array}$ \\
\hline United States: SMSA's & & & & \\
Chicago & 6311 & 793 & 67.9 & $63.2 \%$ \\
Denver & 6016 & 625 & 71.2 & $50.5 \%$ \\
Detroit & 6314 & 698 & 65.6 & $66 \%$ \\
Houston & 1434 & 2889 & 52.3 & $75.7 \%$ \\
Kansas City & 5161 & 1420 & 68.7 & $61.5 \%$ \\
Los Angeles & 1425 & 1085 & 27.7 & $73.9 \%$ \\
San Antonio & 1570 & 2994 & 55.8 & $64.5 \%$ \\
S.F./Oakland & 2975 & 118 & 28.4 & $77.8 \%$ \\
\hline
\end{tabular}

DEFINITIONS: Degree days measured from $65^{\circ} \mathrm{F}$ base. Temperature variance is formed by subtracting average daily minimum January temperature from average daily maximum July temperature. Relative humidity is daily average. Mexican degree days calculated by multiplying days per month by average daily temperature per month difference from $65^{\circ} \mathrm{F}$, summed for the year.

DATA SOURCES: Tables of Temperature, Relative Humidity and Precipitation for the World, Meteorological Office, Her Majesty's Stationary Office, London, 1965. (for Mexico)

Wernstedt, Frederick L., World Climatic Data, Climatic Data Press, 1972. (for Mexico)

Climate of the United States, Vol. 1 and 2, Gale Research Company, Detroit, 1980. (for United States)

Weather of U.S. Cities, Vol. 1 and 2, City Reports, Gale Research Company, Detroit, 1981. (for United States)

Returning to the potential utility gains to be had from movement from Mexico to the U.S., Table 1 shows a comparative listing of climate amenities of the type found to be important to the flow of migrants internally within the U.S. (see Graves, 1979). Several origin areas are described in the table along with a representative set of destination areas in the U.S. Most of the U.S. destinations are colder than their Mexican counterpart, as seen in the first two columns of the table. Since many Mexican origins are quite warm, temperature levels may (or may not) represent a utility gain. On the other hand, there appears to be greater temperature variance, typically, for the U.S. cities and temperature variance has been shown to be undesirable to migrants (this could be interpreted in a biological discomfort way or could be interpreted as a pure cost of living variable-for example, both warm and cool clothing would be required in high temperature locations). There appears to be little systematic difference in average July relative humidity in the cities compared.

This table is only presented as suggestive of the nature of the information that might be obtained in order to assess the supply of amenities in the U.S. and Mexico. Even if amenities were on net favorable in the U.S., rents might more than compensate, leaving potential migrants worse off. This would be expected if high-priced amenities are also superior amenities as has been argued by Graves (1983). The higher average incomes in the U.S. might, for example, result in rents in San Diego being higher than the value of the San Diego amenities to Mexican migrants - this would offset, at least, to some extent, the wage advantages of working in San Diego relative to an origin city in Mexico. This example makes clear that a good bit of information, not currently available in convenient form, would need to be gathered before more refined estimates of the utility gains from movement can be properly gauged.

What of the future? Will migrant flows, whether legal or illegal, increase or decrease? As to sociodemographic traits, the rapid development of Mexico in the recent past has several implications for the migration flows to the U.S. The net impact, given information at hand, is however ambiguous. Should U.S. amenities be superior goods relative to Mexican amenities on net, then rising Mexican incomes 
should lead to greater inflows. Moreover, the nature of those flows in terms of destination will likely be affected by the higher average education usually associated with development. On the other hand, development is likely to result in an increasing average age of the population as fewer children per family are born. This increase in average age will retard movement to the U.S. Perhaps more importantly, rising real incomes in Mexico will likely lead to greater provision of those amenities which are endogenous to the economic system (public parks, various infrastructure improvements, better domestic school systems at various levels, and so on). Hence, increased demands for amenities at higher income levels need not imply increased migration to the U.S. if many of those amenities can be domestically supplied.

Should the Mexican development occur unevenly, leading to an increase in income inequality, an alternative scenario is possible. Some of the relatively poorer Mexican migrants may knowingly seek out low amenity locations for which they can receive compensation in the form of relatively higher wages and lower rents. This can account for the growth now and in the future of hispanic neighborhoods in, for example, Chicago and Detroit. In order to reduce the income inequality within Mexico, many Mexicans send a portion of their earnings back to families in Mexico (Greenwood and Lillydahl, 1982, indicate that perhaps one-third of Mexican migrant earnings are repatriated). Particularly in light of the high compensation available in the land and labor markets in undesirable locations within the relatively prosperous U.S., the utility maximizing migrant may wish to take his utility gain in cash form; this is all the more likely in view of the low amenity demands from those Mexicans at the bottom of their income distribution.

The thrust of efforts to explain and predict the future of migration flows to the U.S. from Mexico must, if they are to be successful, focus on both the characteristics of origins and destinations (and how those will change) and on the characteristics of the origin populations (and how those will change, since sociodemographic and economic changes affect the demand for amenities as well as general mobility patterns). Careful accumulation of data of the type suggested here, from census and other sources, should result in more accurate estimates than would otherwise be possible.

\section{Conclusions}

The role of amenities in migration flows within the U.S. is, by now, beyond question. Recognition of this fact has substantially altered the way migration is modeled within the U.S. However, the insights obtained from such within-country analyses have yet to spill over in a meaningful way to the international migration setting. To some extent this is understandable in that the existence of a border at which clear evidence of disequilibrium, arbitragible utility gains is seen suggests that the pure equilibrium model is not fully applicable.

But the fact that a model is not fully applicable does not mean that it does not shed important light on a class of related events. The model presented here leads to a much deeper understanding of the underlying influences giving rise to the observed legal and illegal flows of migrants into the U.S.

Since considerable evidence from urban economics suggests that the ultimate amenity may be neighbors, the fact of substantial past migration would, alone, suggest considerable migration flows in the future. This is a view which is enhanced by the information cost arguments involving job search aid and support of other types provided by "pioneer" migrants. Yet, to say migration will, for these reasons, continue and increase in future years may well be simplistic, given the arguments here. Growing supplies of domestic amenities and changing demographic and social traits could easily offset tendencies for migratory flows to increase. Indeed, it may well be that the utility gain from crossing the border is much smaller than would be suspected based on income differentials and what gap remains could close quickly. Assessing the future of interactions at the Mexican/U.S. border is far more complicated than a cursory examination based on traditional models might suggest. 


\section{REFERENCES}

Graves, P.E., "A Life-Cycle Empirical Analysis of Migration and Climate, by Race," Journal of Urban Economics, Vol. 6 (1979), 137-47.

Graves, P.E., "Migration with a Composite Amenity: The Role of Rents," Journal of Regional Science, Vol. 23, No. 4 (November, 1983), 541-46.

Graves, P.E., and P. Linneman, "Household Migration: Theroretical and Empirical Results," Journal of Urban Economics, Vol. 6 (1979), 383-404.

Graves, P.E., R.L. Sexton, and T.A. Knapp, "A Multidisciplinary Interpretation of Migration: Amenity Capitalization in Both Land and Labor Markets," The Annals of Regional Science, Vol. 18, No. 2 (July 1984), pp. 35-44.

Greenwood, M.J. and J.H. Lillydahl, "Some Possible Economic Consequences of International Migration: A Survey with Special Reference to the United States and Mexico," (mimeo, University of Colorado, September, 1982).

Greenwood, M.J., J.R. Ladman, and B.S. Siegel, "Long-Term Trends in Migratory Behavior in a Developing Country: The Case of Mexico," Demography, Vol. 18, No. 3 (1981), 369-88.

Hansen, N. The Border Economy, University of Texas Press, Austin, 1981.

Linneman, P. and P.E. Graves, "Migration and Job Change: A Multinomial Logit Approach," Journal of Urban Economics, Vol. 14 (November, 1983), 263-79.

Mundell, R.A., "International Trade and Factor Mobility," American Economic Review, Vol. 47 (1957), 321-25.

Rosen, S., "Hedonic Prices and Implicit Markets: Product Differentiation in Pure Competition," Journal of Political Economy, Vol. 82 (1974), 34-55.

Samuelson, P.A., "International Trade and the Equalization of Factor Prices," Economic Journal, Vol. 58 (1948), $163-84$.

Samuelson, P.A., "Prices of Factors and Goods in General Equilibrium," Review of Economic Studies, Vol. 21 (1953), 1-20.

Schultz, T.W., "The Value of the Ability to Deal with Disequilibria," Journal of Economic Literature, Vol. 13 (1975), $827-46$. 